\title{
Teaching NeuroImages: Evolving trans-synaptic degeneration of retinal ganglion cells after occipital lobe stroke
}

Jonathan A. Micieli, MD, Richard J. Blanch, MB ChB, PhD, and Kannan Narayana, MD

Neurology ${ }^{\circledR}$ 2018;90:e2179-e2180. doi:10.1212/WNL.0000000000005686

A 59-year-old woman presented with acute left-sided visual field loss. A left homonymous hemianopia without a relative afferent pupillary defect and corresponding right occipital stroke on MRI were noted (figure). Optical coherence tomography of the macular retinal ganglion cell complex (GCC) showed GCC loss corresponding to the area of visual field loss in the left eye first, 100 days later (figure). The left eye was affected earlier and to a greater degree, which is consistent with previous animal studies, ${ }^{1}$ and may be due to the larger temporal visual field and larger number of crossing fibers. ${ }^{2}$

\section{Author contributions}

Jonathan Micieli: study conception and design, manuscript preparation. Richard Blanch: study conception and design, manuscript preparation. Kannan Narayana: study conception and design, acquisition of data, final approval of manuscript.

\section{Study funding}

No targeted funding reported.

\section{Disclosure}

The authors report no disclosures relevant to the manuscript. Go to Neurology.org/ $\mathrm{N}$ for full disclosures.

\section{References}

1. Théoret H, Herbin M, Boire D, Ptito M. Transneuronal retrograde degeneration of retinal ganglion cells following cerebral hemispherectomy in cats. Brain Res 1997;775:203-208.

2. Dinkin M. Trans-synaptic retrograde degeneration in the human visual system: slow, silent and real. Curr Neurol Neurosci Rep 2017;17:16.

\author{
Correspondence \\ Dr. Narayana \\ kannan.narayana@ \\ emory.edu
}

\section{MORE ONLINE}

\section{$\rightarrow$ Teaching slides}

links.lww.com/WNL/A557 
Figure Evolving retrograde trans-synaptic degeneration of retinal ganglion cells
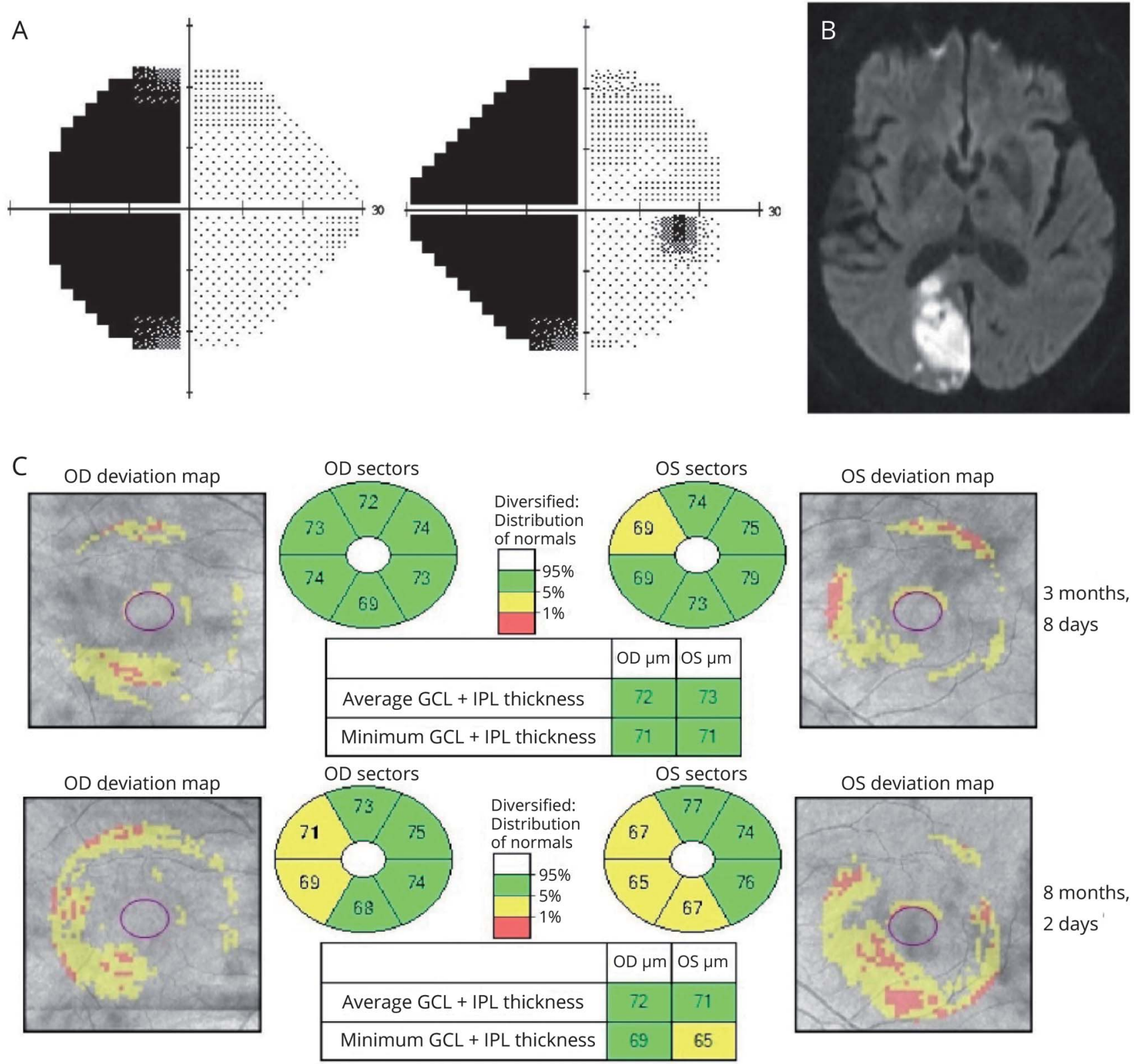

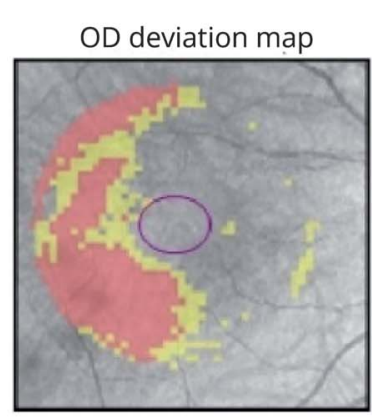

Right eye

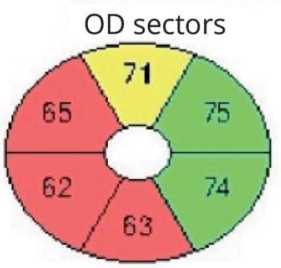

\begin{tabular}{|l|c|c|}
\hline & OD $\mu \mathrm{m}$ & OS $\mu \mathrm{m}$ \\
\hline Average GCL + IPL thickness & 68 & 68 \\
\hline Minimum GCL + IPL thickness & 60 & 57 \\
\hline
\end{tabular}

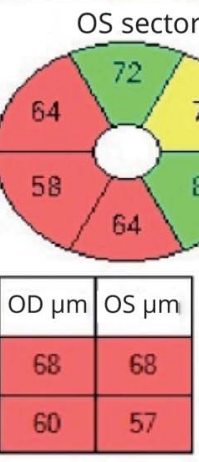

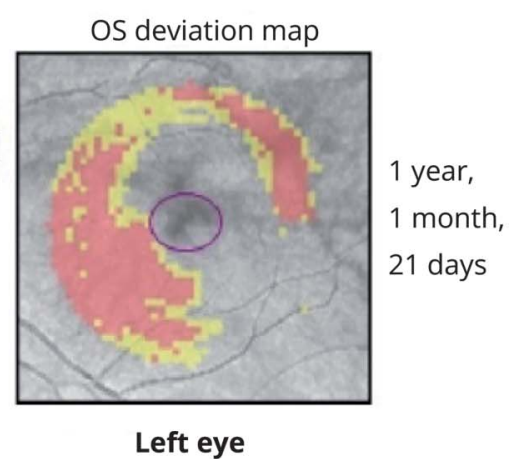

Humphrey visual field test demonstrates a left homonymous hemianopia (A) with corresponding restricted diffusion in the right occipital lobe (B). Optical coherence tomography of the macular ganglion cell complex (C) starts to show thinning in the nasal retina of the left eye about 100 days after vision loss that increased with time in both eyes. GCL = ganglion cell layer; IPL = inner plexiform layer. 


\section{Neurology}

Teaching NeuroImages: Evolving trans-synaptic degeneration of retinal ganglion cells
after occipital lobe stroke

Jonathan A. Micieli, Richard J. Blanch and Kannan Narayana

Neurology 2018;90;e2179-e2180

DOI 10.1212/WNL.0000000000005686

\section{This information is current as of June 11, 2018}

\section{Updated Information \&} Services

References

Subspecialty Collections

Permissions \& Licensing

Reprints including high resolution figures, can be found at: http://n.neurology.org/content/90/24/e2179.full

This article cites 2 articles, 0 of which you can access for free at: http://n.neurology.org/content/90/24/e2179. full\#ref-list-1

This article, along with others on similar topics, appears in the following collection(s):

Infarction

http://n.neurology.org/cgi/collection/infarction

Retina

http://n.neurology.org/cgi/collection/retina

Visual fields

http://n.neurology.org/cgi/collection/visual_fields

Information about reproducing this article in parts (figures,tables) or in its entirety can be found online at:

http://www.neurology.org/about/about_the_journal\#permissions

Information about ordering reprints can be found online:

http://n.neurology.org/subscribers/advertise

Neurology ${ }^{\circledR}$ is the official journal of the American Academy of Neurology. Published continuously since 1951, it is now a weekly with 48 issues per year. Copyright () 2018 American Academy of Neurology. All rights reserved. Print ISSN: 0028-3878. Online ISSN: 1526-632X.

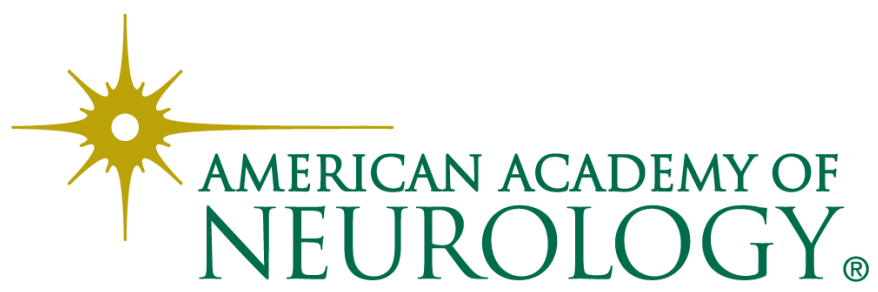

